\title{
Family Group Conference and its Role in addressing Homelessness Worldwide
}

\author{
J. Miklosko (Jozef Miklosko), E. Bezakova (Emilia Bezakova) and J. Herak (Jan \\ Herak)
}

Original Article

St.Elizabeth University of Health and Social Work, Bratislava, SK

Field office of the St.Elisabeth University - Society Usmev ako dar, SK

\section{E-mail address:}

mikloskovamonika@gmail.com

\section{Reprint address:}

Field office of the St. Elisabeth University

Society Usmev ako dar

Sevcenkova 21

85102 Bratislava, SK

Suource: Clinical Social Work and Health Intervention

Pages: $30-38$

Volume: 8

Cited references: 14

Issue: 1

\section{Reviewers:}

Dr. Steve Szydlowski, MBA, MHA, DHA

University of Scranton School of Education, USA

Prof. Dr. Selvaraj Subramanian, Ph.D.

SAAaRMM, Kuala Lumpur, MY

\section{Key words:}

Family Group Conference, Child, Family, Social skills.

\section{Publisher:}

International Society of Applied Preventive Medicine i-gap

CSWHI 2017; 8(1): 30 - 38; 10.22359/cswhi_8_1_07 ( C) 2017 Clinical Social Work and Health Intervention

\section{Abstract:}

All over the world is proved the effectiveness of the conferencing model of the work with the social and family network. A proven effective way for enhancing and strengthening the family system is conducting meetings and family circles. Family Group Conferences (FGC) as the old, but newly uncovered way of the social work, definitely has important 
role also in the homelessness issue. Content analysis conducted interviews with 42 members of 14 families and 16 professionals who participated in FGC, we have identified supporting factors strengthening the family system through implementation FGC in homelessness issue.

\section{Objective:}

In 40 countries of the world there is the Family Group Conference model used in the solving homeless issue. The aim of our research was to discover the impact of the using Family Group Conference model in the social work with the family at the solving family homelessness.

\section{Design:}

Pilot study.

\section{Participants:}

The 42 clients suffering by the homelessness problem participated in the study and 16 professionals involved in Family Group Conference interviewed during one year period (2015-2016). Original Articles 8 Clinical social Work and Health Intervention Clinical Social Work and Health Intervention Vol. 8 No. 12017

\section{Methods:}

Qualitative research (semi-structured interviews) were evaluated by Atlas program by the methodology based on the grounded theory.

\section{Results:}

Partcicpants defined supporting factors which influenced more effective solving their homeless problem by the using Family Group Conference model.

\section{Conclusion:}

The pilot study shows that Family Group Conferences improves the quality of life and contribute to the more effective solutions of the homelessness issue. However, there is a need for prolonged study with more clients in order to demonstrate the effectiveness of this model.

Professor Jozef Mikloško, PhD. since his undergraduate study devoted to multidisciplinary attitude to the family issue. His long-term interest in the prenatal psychology and medicine is used at the Institute of prenatal and perinatal medicine, psychology and social sciences of the St. Elizabeth University.
As a co-founder of Smile as a gift (1991) and since 1992 as a chairman of this professional NGO he is involved in systematical and conceptual changes in the field of child protection system and family policy. As a member of the Committee of Experts on deinstitutionalization calls for positing new pro-family starting points in substitutional 
care as a member of the Committee for Children and Youth of the Government Council for Human Rights, national minorities and Gender equality promotes the principles of strengthening the rights of children and their families in our society. Emília Bezáková, PhD and Ján Herák are colleagues cooperating with professor Mikloško on the conceptual and research work.

\section{Introduction}

More recently, some local authorities have developed services using the Family Group Conferencing (FGC) model to address the needs of adult service users and their families including elder abuse, children learning disabilities, adults with mental health difficulties, internationally they are also used to plan for release of prisoners from jail, for discharge of adults from hospital and in addressing homeless and debt.

In Slovakia is nowadays critical situation in the issue of homelessness of the families. Many children cannot live with their parents becouse of lack of housing possibilities. The reason of the separation the children from their families is not lack of the interest of the parents to take care about their children, but lack of their social skills and lack of the economic and social securities for the families.

An alarming outcomes brought the research of the reasons out of home placement of the children (Mikloško, 2014), interesting comparation of these results is available through the current data of the reasons preventing the child's return from the children's homes to the family which we have been taken by Úsmev ako dar 2014, and presente in the attached Chart No. 1.

Chart No. 1 What prevents the child from his/her return to the family (multiple response)

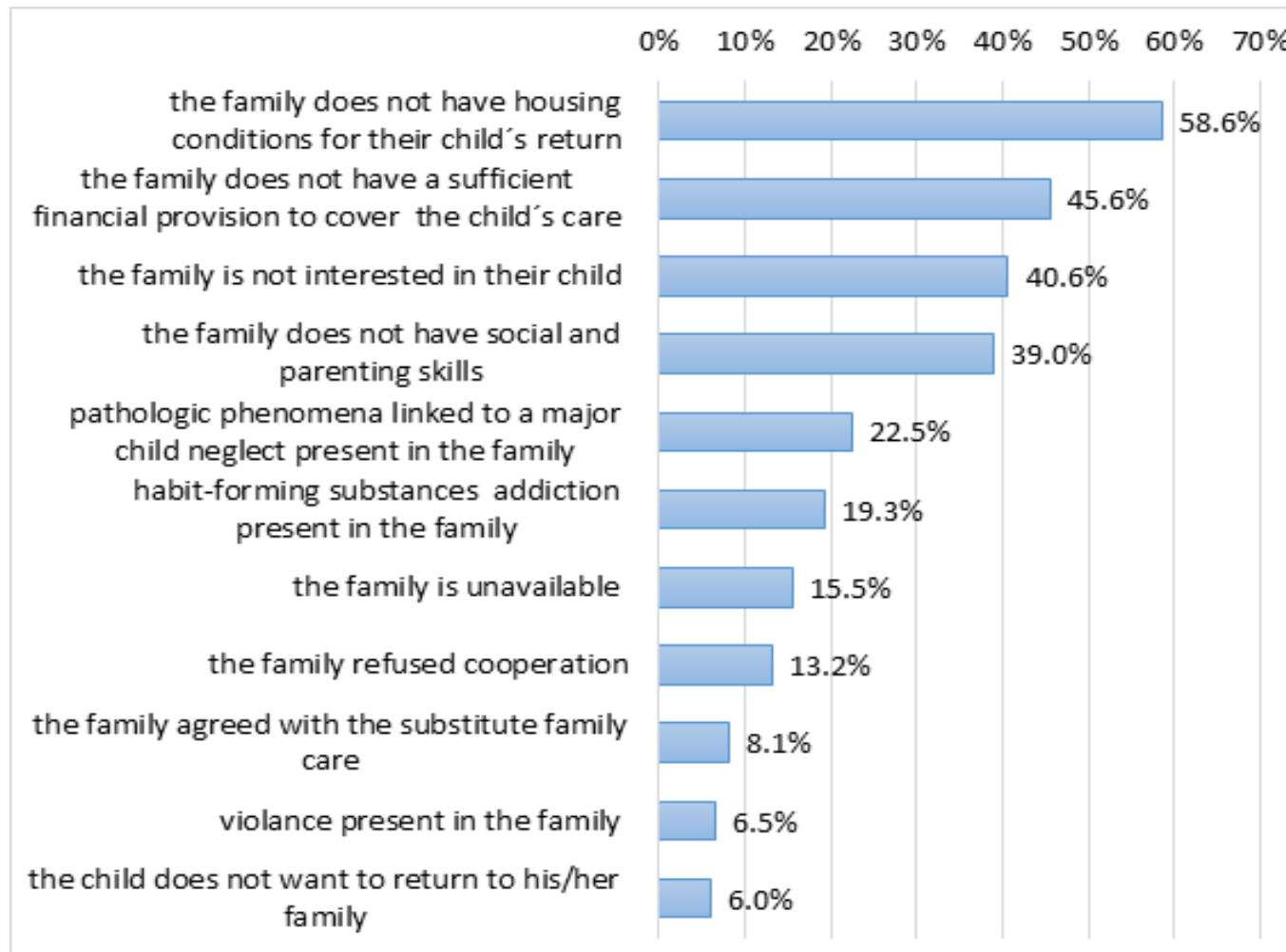

Source Data collection on children in residental children homes, UaD, 2014 
The research outcomes of the out of home placement of the children from the families (Mikloško, 2014) and the research of the factors influencing reunification of the children with families (Miklošková, Fero, Bytčáneková, 2016) confirms that not character of reasons as a single factor determines the chance of the child to return home, but the support provided and the possibility to solve the reasons leading to the exclusion.

The exclusion of children from the families being identified by research results, therefore, despite the complexity and severity, have been proved as not impassable causes of separation of children from their families, yet, they are a significant signal for system changes in the social legal protection system. The prevailing economic character of the reasons that have been repeatedly cited by the competent authorities' social workers in the research Vulnerable families 2006-2013 (Mikloško, 2014) is fundamentally contrary to the Family Act No.36 / 2005 Coll, which excludes economic reasons for taking out a child from his/her family.

A Family Group Conference can modestly contribute to the solution of the actual situation and shake with the stagnation and sence of insulation of the week family member. FGC opens new doors and initiate new energy of the family system. FGC brings together the family (and extended family members, friends and neighbours) to plan and make decisions to safeguard and promote a child's welfare.

\section{History of FGC}

Family group conferences draw upon Maori culture and their development was a response to the large number of Maori children being removed into state institutions. Family group conferences are now recognised in law (The Children, Young Persons and their Families Act 1989) in New Zealand as being the key process by which families make informed and responsible decisions, recommendations and plans for their children and young people. In fact it is a requirement that before any child can be taken into state care, a referral for a family group conference must be made. They also form part of decision making in New Zealand's youth justice system.

\section{What is Family Group Conferencing?}

The Family Group Conference is the meeting of the extended family and the social network of the family prepared by an independent coordinator (outsider), who has absolutely no other connection with the family. The family and their group of close people to the child, who are brought together, want to create a plan that includes decisions intended to decrease or eliminate certain problems or risks for a child within the family, or within institutional care.

Together with professionals, the family and members of their social network share their concerns, knowledge and experience. Afterwards, the family meets alone, without other people, to draw up a plan that includes the precisely described agreements. The legally appointed guardian/family supervisor then endorses the plan on the condition that it is safe for the child and meets the child's needs and also legal requirements.

FGCs are generally structured to incorporate four distinct stages:

\section{- Referral:}

Family members and agency agree that $\mathrm{FGC}$ is required and co-ordinator is appointed.

- Preparation:

Co-ordinator identifies family network, meets with people attending to discuss the reason for the meeting and invite them to participate.

\section{- Meeting:}

Agency staff and/or other parties provide information to enable the family 
to develop a plan for the child, everyone attending discusses situation, family meets in private to discuss plan, plan is deliberated upon, amended if necessary and agreed by all attendees. In some situations the plan may then need to be agreed by another forum e.g. child protection case conference.

\section{- Review:}

Operation of plan is reviewed, FGC may be convened to amend/replace plan.

In the Family Group Conference all resources around a family system are brought together by a trained and precisely prepared coordinator. Those present discuss in seclusion, without referrer, social care worker and coordinator, what the issue is and what plan is fitting, using their own resources. The benefit of this is that it does not depend on the capabilities of the system, case manager and social care worker to formulate the care need, but allows the family to retain responsibility for their child and make solutions using their own resources and the resources of their social network. Based on the plan as formulated by the family, the social care worker offers the services required.

\section{Results of the FGC model}

Research of the FGC model reports very interesting results regarding the success of the model. The plans of the families show the potential and possibilities of attending family network members, it can be interpreted that they are interested in contributing to the improvement of the life of the child with whom they have a relationship, mutual history and specific ties.

Along with research of 10.000 FGCs (Pagée, 2016), in around $75 \%$ of the referrals an independent coordinator was able to establish the cohesion needed to result in a conference. Half of the families in the remaining
$25 \%$ of the cases arrived at a solution without the need for an official conference, and the other half was unable to organize a conference due either to the lack of safety this would involve or for other reasons. On average, thirteen people take part in a conference and they arrive at eighteen agreements.

A distinctive feature of these conferences is that they often ignore the tunnel vision approach typical of professional care providers and seek coherence in solutions involving an average of at least four general areas of their lives (such as housing, finances, health and education). Many agreements (around 80\%) have the family group itself accept responsibility for what needs to be done. The other 20\% involve having the family ask for assistance from subsided professional services. Within three months, the majority of the agreements have been met by the family members. And satisfaction concerning the conference is great among children, parents, other family members and the professionals. FGC professionals and tradition say that $67 \%$ of family plans are better and $33 \%$ are as good as their own plans for the family. No plan is less evaluated. Re-abuse after FGC is declared at $6 \%$ after a FGC (normally $16-25 \%$ in traditional social work). With social workers $78 \%$ of plans are successful even after 1.5 years. (Pagée, 2016).

\section{Objective}

This review of research and practice in Family Group Conferencing was undertaken during 2015 -2016 in the Smile as a Gift (NGO) -FGC Centre in Slovakia. It comprised two distinct, but complementary parts: FGC agenda reviews and interviews with the family members and professionals who have participated in Family group Conferences. The aims of the research were to review evidence of the impact of FGC for families with socio-economic problems 
and homeless problem and to gather views about the influence and experience of FGC on their family life.

\section{Results}

Factors strengthening the family system through implementation Family Group Conferencing model (communicated by professionals)

a. Positive experiences and concrete outcomes coming out of the FGC of the research are consistently proclaimed by all participants (stakeholders, family members, memebrs of the wide social netwporks)

b. Among family members interviewed, FGC was widely valued as a means of healing, empowering, linking and initiating families and translating the rhetoric of best interest of a child into practice. It was recognised that best interest of a child can be difficult issue in the present climate of professionally led, risk averse practice. FGC was also viewed as a way of according children the rights to participate in decisions affecting them and, if possible, to be cared for within their own family.

c. In terms of its practical benefits, FGC was viewed as an effective means of producing comprehensive and realistic plans for family which were created by the wider family. It was regarded as a task-centred decision-making and widening circle process which, although not designed to achieve this, may strongly contribute to improvement and change of family atmosphere and relationships.
Factors strengthening the family system through implementation Family Group Conferencing model (communicated by family members)

1. A better understanding of the problem and its context within the family "I did not understand before, what exactly they want from me. Nothing it was not good. Still, I was under a lot of pressure.

2. Breaking the social isolation of families, supporting the establishment of new relations for the family "I did not believe it, what's there and promised to comply with that can we really take time for yourself."

3. Reconnective the previous promotion of relations

"They did not know what to make of us have to think when our children married, dodging us now understand what happened and how it before, I mean, I think even better ..."

4. Finding and engaging a broader support network of family

5. Improved relations in the family system

6. Increase understanding towards the needs of the child

"I finally understand why we are still arguing, I understand what my team is still sulking about to say"

7. Increase confidence in the professionals

„Now I believ she really want us to help, not to judge us“".

8. Confirmation of self-worth family members

"After a long time anyone has actually listened and tried to understand me"

9. The demonstration of the mutual respect and the respect of involved professionals

"They talked with me, as between themselves, no one did not point the finger at me" 
10. Confirmation of the parental role in their children's lives, acknowledgment of responsibility for child "They talked to me like I was still mom did not talk about me like some of what failed, they said:" Your children need you."

11. A sense of acceptance by the wide family and wider social network

The unique aspects of implementing family group conferencing with homeless people.

- the timing of conferences,

- the specific needs of the homeless people,

- the use of modifications/alternatives to casual FGC,

- help with access to informations,

- the clear role of the professionals

Factors on the family side affcting the reunification of a child with the homeless parents are:

- ethnicity of families (less favorable to reunificate are children with perceived Roma ethnicity)

- the nature of community of the child's family

- the region where the family lives,

- cooperating behavior of professionals with parents after the separation,

- the living situation of the parents

- parents' attitude to the solution of problems that were behind the exclusion of the child from the family

\section{Conclusion}

In the most of the interviews FGC was viewed as a practically effective way of working with families whose strengths and resources often remain untapped by mainstream practice. In terms of the research evidence, it is well established that most participants are positive about the FGC process and that, with appropriate information and support, extended families can develop plans which are acceptable to social work services. The enthusiasm of family members and professionals who have experience of FGC is impressive. They give many examples of professionals who change their minds and families who have been helped to make practical plans and sometimes significant changes through their involvement in this process.

\section{Families who are homeless or at risk of being homeless}

It is perhaps with families who are homelss or at risk of being homeless that the use of FGC is most straightforward. Avoiding a family being homeless is a very clear and pressing reason for involving the wider family and wider social network. FGC was used widely for children away from home or being considered for a care placement becouse of homelesness of the family. In some instances family members were able to offer children a home. In others, FGC resulted in very close contact arrangements which allowed children to have a continuing sense of belonging to a family, even if out of home placement is necessary. Both outcomes were acknowledged as potentially extremely beneficial for children.

Correspondingly, developing contact plans or support which will enable a child to return home from the crisis centre or children' s home brings family responsibilities clearly into focus. A number of respondents gave examples of family or social network members agreeing to care for children untill parents find the housing and sustaining the arrangement over several months. FGC enable children stay with close people during the crisis situation in the family, so that the child would have a continuing sense of belonging and people to support family connection during time of separation. 
Problematic issue is social worker resistance to refer the need of FGC, so introducing procedural mandate promoted this development. Different views were expressed about the stage at which it was best to involve the extended family, with some respondents favouring early intervention and others suggesting that the wider family was more likely to engage in response to a specific risk e.g. when out of home placement was being considered.

We learned much from our practice about conducting Family Group Conferences. Over time, we started to be able to answer significant questions, most of which came from care professionals who saw an approaching change in their roles.

The aim of the paper was to find out the supportive factors of the family empowerment to solve their socio-economic situation and homelessness by Family Group Conferences.

The research results show the potential and importance of the Family Group Conference model in facing homelessness issue. We believe that our work will contribute to understanding the importance of more intensive support of the natural family relationships and to supporting the process of planned system changes aimed at pro-family wide networking social work.

\section{Acknowledgements}

The work has not been presented before. There was no funding for the research.

\section{Conflicts of interest}

None declared.

\section{Reference}

1. KOVAC R., MIKLOSKOVA M. (2013). The Impact of Early Childhood on the Risk of the Homelessness, p. 80 - 89. In: The International
Journal of Prenatal and Perinatal Psychology and Medicine, Volume 25, Supplement 1, 2013, Society of Integrated sciences. ISBN 0943-5417

2. HAMILTON A. (2005) Releasing the Power of the Family: Children 1st and Family Group Conferences 1999-2005, Edinburgh: Children 1st . Hardin, M. (1996) Family Group Conferences in Child Abuse and Neglect: Learning from the Experience of New Zealand, Washington: ABA Centre on Children and the Law.

3. LUPTON C. \& NIXON P. (1999) Empowering Practice?: A Critical Appraisal of the FGC approach, Bristol: Policy Press. Lupton, C. \& Stevens, M. (1997) Family Outcomes: Following Through on Family Group Conferences (Report No. 34), SSRIU, Portsmouth: University of Portsmouth.

4. MIKLOSKO,J., MIKLOSKOVA, M.(2013). Empowering family Realtionships and Supporting the Family Network as one of the Solutions for a Child in Distress, p. 104 116. In: The International Journal of Prenatal and Perinatal Psychology and Medicine, Volume 25, Numbers 1 - 2, 2013, Society of Integrated sciences. ISBN 0943-5417

5. MIKLOSKO J., MIKLOSKOVA M. (2013). Family Protection and Social Work with Families. In: Nandoya S.E., Mbwau M.K., Ng'Endo A.N., Benca,J. Emerging Issues in Social Work and Community Heath in Subsaharan Africa versus EU, Hope for poor and sick, Nairobi, 2013. p.308-330, ISBN 978-9966-21-043

6. MIKLOSKO, J., MIKLOSKOVA, M. BEZAKOVA,E., MRAZKOVA,I., SEBOVA,N. HUDEKOVA,A. (2013). Children at risk during the early stages of their developlment in crisis families in Slovakia. p.42-69. The International Journal of Prenatal and Perinatal Psychology and Medicine, Volume 25, Supplement 1, 2013, Society of Integrated sciences. ISBN 0943-5417

7. MIKLOSKOVA, M. (2012). Family conference as a means of strengthening and 
exploitation of the social fabric of the child and his family. p.131 - 142. In: Mikloško, J. Quo Vadis Slovak family, 2012. SPDDD ÚaD, Slovak Society for Family, IOPDR pri FZaSP TU, 234 p. ISBN 978-80-970879-1-3

8. MIKLOSKOVA M. Meeting the family circle. (2013). In: Socioterapia. Ročník III, číslo 4. ASSP, Bratislava. 2013. p.6-7. ISSN $1338-7138$

9. MIKLOSKOVA M. (2014). Meeting the family circle in the system of social protection of children.. p.98-117. In: Mikloško,J. a kol. (2014). Development of the situation of vulnerable families in Slovakia between 2006 and 2013. The company Smile as a gift in cooperation with the Institute for protection of the rights of the child and the family of the Faculty of Health and Social Work of Trnava and the Central Office of Labour, Social Affairs and Family. Bratislava 2014. ISBN: 978-80-970879-5-1

10. MIKLOSKOVA M., FERO, M., MIKLOSKO, J. (2016). Problematic Behaviour of Children in Institutional Care-a problem for the adults taking care of them. How can we eliminate behavioral problems of children separated from their families? In: Suvada J.,
Czarnecki P., Tomanek, P. Social Pathology, Updates 1. Warsaw Management University Publishing House, Warsaw, 2016. p. 135 154, ISBN 978-83-7520-206-9

11. MIKLOSKOVA, M, FERO, M. BYTCANEKOVA, J. (2016). The reunification of the child with the family - factors on the family side influencing the child's return from the institutional care In: Suvada J., Czarnecki P., Bujdova N. Social Pathology within the Family, Warsaw Management University, Warsaw 2016, ISBN 978-837520-218-2

12. MINAROVICOVA, K. (2013). Emotional frustration of children in children 's homes. In Prenatal and Perinatal Psychology and Medicine, 25, n.1-2, 2013. P. 117-120. ISSN 0943-5417.

13. MINISTRY OF LABOUR, SOCIAL AFFAIRS AND FAMILY OF THE SLOVAK REPUBLIC (2014). Statistic of the Institutional care. Available from: http://www.employment.gov.sk

14. PAGÉE R (2016). Training for FGC coordinators, March 2016, Banská Bystrica, Slovakia.

15. WWW.USMEVAKODAR.SK 